\title{
Androstenedione and Its Conversion to Plasma Testosterone in Congenital Adrenal Hyperplasia *
}

\author{
R. Horton † ANd S. D. Frasier \\ (From the Departments of Medicine and Pediatrics, University of California, Los Angeles, \\ School of Medicine, Los Angeles, Calif.)
}

Summary. The plasma concentration, production rate, and conversion ratio of androstenedione and testosterone were studied in seven children with congenital adrenal hyperplasia $(\mathrm{CAH})$ of the 21-hydroxylase type. Plasma androstenedione and testosterone measured by double isotope derivative assay and estimated blood production rates were manyfold increased in the untreated state, markedly suppressed with glucocorticoid, and increased after the administration of ACTH.

The metabolic clearance rate when corrected for body size and the conversion ratio of androstenedione to testosterone were similar to previously determined values in normal adults. Consideration of the androgen concentrations and conversion ratios indicates that in children with $\mathrm{CAH}, 76 \%$ of the plasma testosterone in prepubertal females and $36 \%$ in males are derived from peripheral conversion of blood androstenedione. The calculated amount of testosterone unaccounted for by peripheral conversion is similar to normal prepubertal values. This approach indicates that virilization in these children results from increased levels of testosterone but that the major source in CAH of this potent androgen is androstenedione secreted by the adrenal cortex.

\section{Introduction}

The major clinical manifestation in patients with congenital adrenal hyperplasia (CAH) of the 21-hydroxylase type is progressive virilization. These abnormalities can be reproduced by the administration of androgenic steroids. In this disorder, an enzyme deficiency in cortisol synthesis and secretion leads to hypersecretion of adreno-

* Submitted for publication December 23, 1966; accepted March 10, 1967.

This work was supported by U. S. Public Health Service grant AM 10019 and grant P-404 from the American Cancer Society. Some of these studies were performed in the Clinical Research Center supported by U. S. Public Health Service grant FR 238.

Part of this work was presented at the Forty-eighth Meeting of the Endocrine Society, Chicago, June 1966.

† Holder of U. S. Public Health Service Career Development Award K3-AM-15,955.

Address requests for reprints to Dr. Richard Horton, Dept. of Medicine, School of Medicine, Center for the Health Sciences, Los Angeles, Calif. 90024. corticotropin (ACTH), which partially overcomes the block, but at the expense of increased secretion of steroid precursors among which are androgenic steroids (1-3).

The nature of the androgenic substance responsible for the clinical manifestations of adrenal hyperplasia has not been clarified. Since testosterone is the most potent natural androgenic hormone and the adrenal is capable of synthesizing testosterone (4), increased secretion of this steroid has been suggested as the responsible mechanism. This hypothesis is supported by the demonstration of increased urinary excretion (5-11), plasma concentration $(10,12-14)$, and production rate $(10-12)$ of testosterone in patients with congenital adrenal hyperplasia. However, recent work by Korenman and Lipsett (15) and Horton and Tait (16) indicates that the weak androgen, androstenedione (androst-4-ene-3,17dione), can be converted by peripheral tissue in vivo to testosterone. Horton and Tait have fur- 
ther demonstrated that almost two-thirds of blood testosterone in the normal female is derived from blood androstenedione. Since an analogous situation might be present in certain clinical states, this study was designed to further explore the in vivo mechanism of virilization in congenital adrenal hyperplasia.

\section{Methods}

Three prepubertal females and four prepubertal males with congenital adrenal hyperplasia were studied. Two children were previously untreated (R.D., F.D.), and five were studied 4 to 6 weeks after suppressive therapy had been discontinued. All patients were significantly virilized in the untreated state with advanced bone age. The diagnosis of congenital adrenal hyperplasia was based on progressive virilization, increased excretion of 17-ketosteroids and pregnanetriol, normal or low 17-hydroxysteroid excretion (Porter-Silber chromogens), and urinary ketosteroid suppression with physiological doses of cortisol or cortisol analogue. Therefore, all patients are considered to have a 21-hydroxylase block.

Urinary 17 -ketosteroids were determined by a modification of the method of Drekter and associates (17), and urinary pregnanetriol was measured by the technique of Cox (18). Normal values for prepubertal children are less than $5 \mathrm{mg}$ per day and less than $2 \mathrm{mg}$ per day, respectively.

Plasma testosterone and androstenedione were measured by double isotope derivative techniques using thiosemicarbazide $-{ }^{35} \mathrm{~S}$ and steroid-1,2- ${ }^{3} \mathrm{H}$ indicator of high specific activity. Testosterone was measured by the method of Riondel and co-workers (19) and androstenedione by the method of Horton (20). The nonspecific blank, accuracy, and sensitivity are as originally described. Greater experience with these techniques has resulted in an equivalent or increased recovery with half the original amount of reagent used $(0.5 \mathrm{mg}$, SA 140 to $160 \mathrm{mc}$ per mmole). This improvement, however, has

TABLE I

Urinary steroid excretion in congenital adrenal hyperplasia $(C A H)$

\begin{tabular}{|c|c|c|c|c|c|}
\hline \multirow[b]{2}{*}{ Patient } & \multirow[b]{2}{*}{ Age } & \multirow[b]{2}{*}{ Sex } & \multicolumn{2}{|c|}{ Untreated } & \multirow{2}{*}{$\frac{\begin{array}{c}\text { Cortisol } \\
\text { suppression }\end{array}}{\text { Ketosteroid }}$} \\
\hline & & & $\begin{array}{c}\text { Urinary } \\
\text { ketosteroid }\end{array}$ & $\underset{\text { nanetriol }}{\text { Preg- }}$ & \\
\hline & years & & \multicolumn{2}{|c|}{$m g / d a y$} & $m g / d a y$ \\
\hline $\begin{array}{l}\text { 1. F.D. } \\
\text { 2. M.P.* } \\
\text { 3. R.S. } \\
\text { 4. R.M. } \\
\text { 5. R.D. } \\
\text { 6. S.S. } \\
\text { 7. D.C. }\end{array}$ & $\begin{array}{r}4 \\
6 \\
10 \\
8 \\
8 \\
9 \\
7\end{array}$ & $\begin{array}{l}M \\
M \\
M \\
M \\
F \\
F \\
F\end{array}$ & $\begin{array}{l}16 \\
10 \\
14 \\
21 \\
25 \\
14 \\
21\end{array}$ & $\begin{array}{l}14 \\
19 \\
15 \\
18 \\
19 \\
13 \\
20\end{array}$ & $\begin{array}{l}5.1 \\
3.4 \\
4.2 \\
4.8 \\
3.3 \\
3.4 \\
4.1\end{array}$ \\
\hline
\end{tabular}

* Salt loser. no bearing upon sensitivity and accuracy, which are primarily dependent upon the variation of the nonspecific blank (21).

The metabolic clearance rate of androstenedione and testosterone and their conversion ratios in blood were determined by constant infusion of tritiated steroid and isolation of infused steroid and its conversion product from plasma as previously described (16). The infusions were all performed between 8 and 11 a.m. The metabolic clearance rate was calculated as the rate of infusion of ${ }^{8} \mathrm{H}$ per day divided by the plasma radioactivity as the infused steroid per liter at equilibrium corrected for recovery. The blood production rate, which is the total amount of hormone entering the general circulation, was calculated as the product of the plasma concentration and the metabolic clearance rate (16). A diurnal variation in plasma testosterone, although of lesser magnitude than cortisol, has been noted in normal adult male subjects (22). Therefore the mean calculated testosterone blood production rate is an estimation of the actual daily blood production rate.

The conversion ratio in blood was calculated as previously described (16) as the ratio of counts per minute ${ }^{8} \mathrm{H}$ per liter corrected for recovery, of product to precursor. Previous work has demonstrated that equilibrium is obtained in blood after infusion of ${ }^{3} \mathrm{H}$-labeled androstenedione and testosterone for 130 minutes and that the chromatographic systems result in radiochemical isolation of both these steroids from plasma (16).

The recoveries, levels of counting, and counting errors of this approach are described in the original paper (16) and extensively discussed in a recent report by Horton and Tait (23).

\section{Results}

Urinary steroids. The urinary steroid excretions of the children with $\mathrm{CAH}$, in the untreated state and after cortisol suppression, are shown in Table I. The mean excretion of 17 -ketosteroids and pregnanetriol in the untreated state was $17 \mathrm{mg}$ per day. No sex differences in these values were noted in these children with $\mathrm{CAH}$.

Treatment with cortisol resulted in a fall in the mean 17 -ketosteroid value to $3.7 \mathrm{mg}$ per day. In all subjects the ketosteroid values reached normal or subnormal levels on low doses of cortisol (20 to $30 \mathrm{mg}$ per day).

Plasma concentration of androstenedione and testosterone in congenital adrenal hyperplasia. The mean concentration of androstenedione (corrected for the mean blank of $17 \mathrm{~m} \mu \mathrm{g}$ per $100 \mathrm{ml}$ ) was $380 \mathrm{~m} \mu \mathrm{g}$ per $100 \mathrm{ml}$ for males and $647 \mathrm{~m} \mu \mathrm{g}$ per $100 \mathrm{ml}$ for females with CAH. Mean plasma testosterone (corrected for the mean blank of 19 $\mathrm{m} \mu \mathrm{g}$ per $100 \mathrm{ml}$ ) was $144 \mathrm{~m} \mu \mathrm{g}$ per $100 \mathrm{ml}$ for 
TABLE II

Plasma concentration of $A$ and $T$, conversion ratios in blood, and contribution of $A$ to $T$ in $C A H$

\begin{tabular}{|c|c|c|c|c|c|c|c|c|c|}
\hline \multirow[b]{2}{*}{ Patient } & \multirow[b]{2}{*}{ Sex } & \multicolumn{2}{|c|}{$\begin{array}{l}\text { Plasma concentration } \\
\text { in untreated patients }\end{array}$} & \multirow[b]{2}{*}{$\mathrm{CR}_{\mathrm{BB}} \mathrm{AT}^{\mathrm{T}} \boldsymbol{0}$} & \multirow[b]{2}{*}{$\mathrm{T}$ from $\mathrm{A}$} & \multirow[b]{2}{*}{$\%$ Total } & \multirow[b]{2}{*}{$T$ from " $T$ " $\dagger$} & \multicolumn{2}{|c|}{$\begin{array}{c}\text { Plasma concentration } \\
\text { after cortisol suppression }\end{array}$} \\
\hline & & $\begin{array}{l}\text { Andros- } \\
\text { tenedione }\end{array}$ & Testosterone & & & & & $\begin{array}{l}\text { Andros- } \\
\text { tenedione }\end{array}$ & Testosterone \\
\hline & & \multicolumn{2}{|c|}{$m \mu g / 100 \mathrm{ml}$} & \multicolumn{3}{|c|}{$m \mu g / 100 m l$} & $m \mu g$ & \multicolumn{2}{|c|}{$m \mu \mathrm{g} / 100 \mathrm{ml}$} \\
\hline $\begin{array}{l}\text { 1. F.D. } \\
\text { 2. M.P. } \\
\text { 3. R.S. } \\
\text { 4. R.M. } \\
\text { 5. R.D. } \\
\text { 6. S.S. } \\
\text { 7. D.C. }\end{array}$ & $\begin{array}{l}\mathrm{M} \\
\mathrm{M} \\
\mathrm{M} \\
\mathrm{M} \\
\mathrm{F} \\
\mathrm{F} \\
\mathrm{F}\end{array}$ & $\begin{array}{l}220 \\
320 \\
320 \\
660 \\
670 \\
720 \\
550\end{array}$ & $\begin{array}{l}120 \\
130 \\
134 \\
190 \\
110 \\
180 \\
120\end{array}$ & $\begin{array}{l}0.17 \\
0.14 \\
0.13 \\
0.14 \\
0.14 \\
0.17 \\
0.16\end{array}$ & $\begin{array}{r}36 \\
45 \\
42 \\
93 \\
94 \\
122 \\
88\end{array}$ & $\begin{array}{l}30 \\
35 \\
31 \\
49 \\
86 \\
68 \\
73\end{array}$ & $\begin{array}{l}84 \\
85 \\
92 \\
97 \\
16 \\
48 \\
32\end{array}$ & $\begin{array}{r}0 \\
28 \\
19 \\
56 \\
23 \\
90 \\
18\end{array}$ & $\begin{array}{r}20 \\
58 \\
70 \\
19 \\
5 \\
0 \\
0\end{array}$ \\
\hline $\begin{array}{l}\text { Mean } \\
\text { Mean }\end{array}$ & $\begin{array}{l}\mathrm{M} \\
\mathrm{F}\end{array}$ & $\begin{array}{l}380 \\
647\end{array}$ & $\begin{array}{l}144 \\
137\end{array}$ & 0.15 & $\begin{array}{r}54 \\
101\end{array}$ & $\begin{array}{l}36 \\
76\end{array}$ & $\begin{array}{l}89 \\
32\end{array}$ & $\begin{array}{l}26 \\
43\end{array}$ & $\begin{array}{r}42 \\
2\end{array}$ \\
\hline
\end{tabular}

* Conversion ratio, androstenedione (A) to testosterone (T), calculated as the ratio of mean androstenedione- ${ }^{3} \mathrm{H}$ and testosterone-8 ${ }^{3} \mathrm{H}$ (Table III).

$\dagger$ Amount of $\mathrm{T}$ in plasma unaccounted for by peripheral conversion of $\mathrm{A}$.

males and $137 \mathrm{~m} \mu \mathrm{g}$ per $100 \mathrm{ml}$ for females with $\mathrm{CAH}$ (Figure 1 and Table II).

Plasma concentrations in male children with congenital adrenal hyperplasia receiving cortisol were $26 \mathrm{~m} \mu \mathrm{g}$ per $100 \mathrm{ml}$ androstenedione and 42 $\mathrm{m} \mu \mathrm{g}$ per $100 \mathrm{ml}$ testosterone, and in females were $43 \mathrm{~m} \mu \mathrm{g}$ per $100 \mathrm{ml}$ androstenedione and $2 \mathrm{~m} \mu \mathrm{g}$ per $100 \mathrm{ml}$ (essentially undetectable) testosterone (Table II).

Metabolic clearance rate $(M C R)$. The metabolic clearance rate of androstenedione ${ }^{3} \mathrm{H}$ $\left(\mathrm{MCR}^{\mathbf{A}}\right)$ in children with $\mathrm{CAH}$ is presented in Table III. The mean $\mathrm{MCR}^{\mathbf{A}}$ was $1,030 \mathrm{~L}$ per day in three female children and $844 \mathrm{~L}$ per day in four male children. Since the children varied considerably in age and body size and these values could not be compared with adult values, they were corrected for body surface. The mean $\mathrm{MCR}^{\mathbf{A}}$ was $1,027 \mathrm{~L}$ per day per $\mathrm{m}^{2}$ for females and $934 \mathrm{~L}$ per day per $\mathrm{m}^{2}$ for male children. There was no significant sex difference in the two groups, and the combined $\mathrm{MCR}^{\mathbf{A}}$ was $970 \pm$ 45 (SE) L per day per $\mathrm{m}^{2}$ (seven subjects). Adult values when corrected for body surface are $1,100 \pm 50$ (SE) $\mathrm{L}$ per day per $\mathrm{m}^{2}$ (twelve subjects) based upon the normal adults studied by Horton and Tait (16) when corrected for body surface area.

Evidence for attaining equilibrium is based upon analysis of radioactivity present at 105 and 120 minutes after the start of the infusion. Taking the value for 105 minutes (135 minutes after load- ing dose) as $100 \%$, the mean value at 120 minutes was $102 \pm 3$ (SE) \% for androstenedione and $98 \pm 3.9$ (SE) \% for testosterone after androstenedione- ${ }^{3} \mathrm{H}$ infusion.

The metabolic clearance rate of testosterone $\left(\mathrm{MCR}^{\mathrm{T}}\right.$ ) in two children [one male (M.P.), one female (S.S.)] with $\mathrm{CAH}$ was 322 and $324 \mathrm{~L}$ per day per $\mathrm{m}^{2}$.

Production rate in blood. The mean production rate in blood of androstenedione in untreated

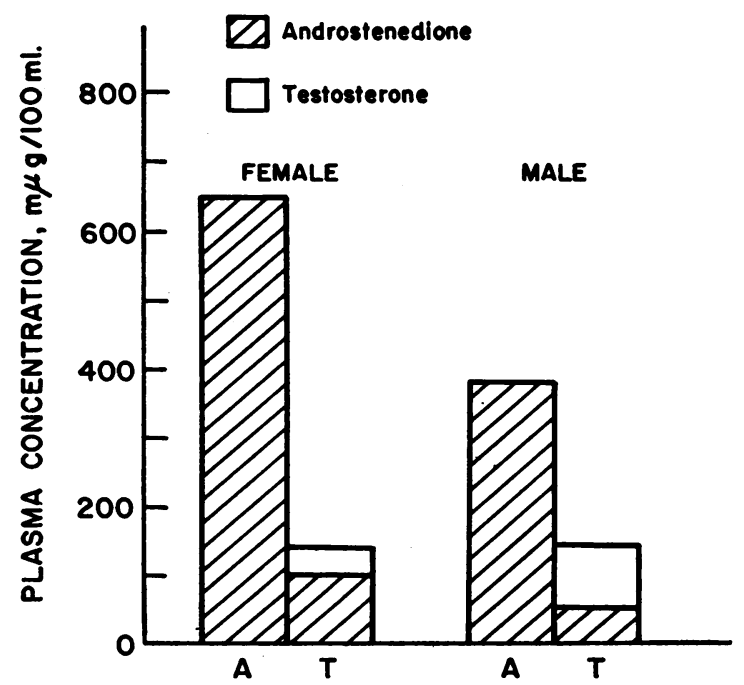

Fig. 1. Androstenedione and testosterone concenTRATION IN PLASMA IN CONGENITAL ADRENAL HYPERPLASIA. The hatched area in the testosterone column represents the contribution of androstenedione by peripheral conversion. 
TABLE III

The metabolic clearance rate and interconversion in blood of androstenedione to testosterone in $C A H$

\begin{tabular}{|c|c|c|c|c|c|c|c|c|c|c|c|c|}
\hline \multirow[b]{2}{*}{ Patient } & \multirow[b]{2}{*}{ Sex } & \multirow[b]{2}{*}{ Age } & \multirow{2}{*}{$\underset{\text { infused }}{\mathrm{A}-{ }^{-3} \mathrm{H}}$} & \multicolumn{3}{|c|}{ Androstenedione $-{ }^{3} \mathrm{H}$} & \multirow[b]{2}{*}{ MCRA* } & \multirow{2}{*}{$\begin{array}{c}\text { Surface } \\
\text { area }\end{array}$} & \multirow[b]{2}{*}{ MCRA $^{\mathbf{A}}$} & \multicolumn{3}{|c|}{ Testosterone- ${ }^{2} \mathrm{H}$} \\
\hline & & & & $130 \mathrm{~min}$ & $145 \mathrm{~min}$ & Mean & & & & $130 \mathrm{~min}$ & $145 \mathrm{~min}$ & Mean \\
\hline & \multirow{3}{*}{$\begin{array}{l}\mathbf{M} \\
\mathbf{M}\end{array}$} & years & $c p m / d a y$ & \multicolumn{3}{|c|}{$c p m / L$} & $L / d a y$ & $m^{2}$ & $L / d a y / m^{2}$ & \multicolumn{3}{|c|}{$c p m / L$} \\
\hline \multirow{2}{*}{$\begin{array}{l}\text { 1. F.D. } \\
\text { 2. M.P. }\end{array}$} & & 4 & $32.0 \times 10^{6}$ & \multicolumn{2}{|c|}{ Pool } & 43,600 & 735 & 0.72 & 1,020 & \multicolumn{2}{|c|}{ Pool } & 7,420 \\
\hline & & 6 & $17.5 \times 10^{6}$ & 28,500 & 29,000 & 28,750 & 610 & 0.70 & 870 & 4,330 & 3,750 & 4,040 \\
\hline 3. R.S. & $\mathbf{M}$ & 10 & $25.8 \times 10^{6}$ & 28,000 & 31,200 & 29,600 & 870 & 1.01 & 860 & 3,680 & 3,770 & 3,725 \\
\hline 4. R.M. & $\mathbf{M}$ & 8 & $19.3 \times 10_{6}$ & 17,000 & 16,200 & 16,600 & 1,160 & 1.18 & 985 & 2,400 & 2,360 & 2,380 \\
\hline 5. R.D. & $\mathrm{F}$ & 8 & $26.7 \times 10^{6}$ & 23,000 & 21,600 & 22,300 & 1,200 & 1.06 & 1,130 & 3,200 & 2,900 & 3,050 \\
\hline 6. S.S. & $\mathbf{F}$ & 9 & $26.64 \times 10^{6}$ & 22,000 & 23,800 & 22,900 & 1,150 & 1.10 & 1,045 & 4,600 & 5,000 & 4,800 \\
\hline \multirow[t]{5}{*}{ 7. D.C. } & $\mathbf{F}$ & 7 & $30.1 \times 10^{6}$ & \multirow{5}{*}{\multicolumn{2}{|c|}{ Pool }} & 40.700 & 740 & 0.82 & 905 & \multirow{5}{*}{\multicolumn{2}{|c|}{ Poo! }} & 6,500 \\
\hline & & & & & & & & Mean & 934 male & & & \\
\hline & & & & & & & & & 1,027 female & & & \\
\hline & & & & & & & & Mean & combined & & & \\
\hline & & & & & & & & & $970 \pm 45(\mathrm{SE})$ & & & \\
\hline
\end{tabular}

$* \mathrm{MCR}^{\mathrm{A}}=$ metabolic clearance rate of androstenedione- ${ }^{-3} \mathrm{H}$.

adrenal hyperplasia, calculated as the product of concentration and metabolic clearance rate, was $6.3 \mathrm{mg}$ per day per $\mathrm{m}^{2}$ in female children and 3.7 mg per day per $\mathrm{m}^{2}$ in male children. With a metabolic clearance rate of $320 \mathrm{~L}$ per day per $\mathrm{m}^{2}$, the mean blood production rate of testosterone in untreated adrenal hyperplasia was $0.44 \mathrm{mg}$ per day per $\mathrm{m}^{2}$ in female children and $0.46 \mathrm{mg}$ per day per $\mathrm{m}^{2}$ in male children.

After cortisol suppression, the calculated blood production of androstenedione was less than 0.5 $\mathrm{mg}$ per day per $\mathrm{m}^{2}$ in all groups. Production rate in blood of testosterone after treatment was unmeasurable in female children and $0.21 \mathrm{mg}$ per day per $\mathrm{m}^{2}$ in prepubertal male children with $\mathrm{CAH}$.

Conversion ratios in blood in $C A H$. The conversion ratio of androstenedione to testosterone in blood $\left(\mathrm{CR}_{\mathbf{B B}}{ }^{\mathbf{A T}}\right)$ in seven children with $\mathrm{CAH}$ was $15 \pm 0.6$ (SE) \% (Table II). There was no sex difference in the children studied. The conversion rate in normal adults has been measured at $14 \pm 1$ (SE) \% (16).

The back conversion of testosterone to androstenedione was $3.4 \%$ and $1.0 \%$ in two prepubertal $\mathrm{CAH}$ children. The $\mathrm{CR}_{\mathbf{B B}}{ }^{\mathrm{TA}}$ in adults is $2.8 \pm 0.2$ (SE) \% (16).

The contribution of plasma androstenedione to plasma testosterone in untreated congenital adrenal hyperplasia. The product of plasma androstenedione concentration and the conversion ratio $\left(\mathrm{CR}_{\mathbf{B B}}{ }^{\mathbf{A T}}\right)$ yields the concentration of plasma testosterone derived from plasma androstenedione, and this with the total concentration of plasma testosterone in the same sample allows calculation of the per cent of plasma testosterone derived from plasma androstenedione from peripheral conversion. This calculation is simplified by the finding that the back conversion is insignificant in terms of actual contribution to androstenedione concentrations in blood. In the prepubertal females with $\mathrm{CAH}, 101 \mathrm{~m} \mu \mathrm{g}$ per $100 \mathrm{ml}$ testosterone, and in the male, $54 \mathrm{~m} \mu \mathrm{g}$ per $100 \mathrm{ml}$ testosterone was derived from the peripheral conversion of androstenedione. This is $76 \%$ and $36 \%$ of total plasma testosterone in female and male children with untreated $\mathrm{CAH}$, respectively (Table II). The remaining amount of testosterone in plasma unaccounted for by peripheral conversion of androstenedione ( $T$ from " $T$," Table II) was 32 $\mathrm{m} \mu \mathrm{g}$ per $100 \mathrm{ml}$ in the female and $89 \mathrm{~m} \mu \mathrm{g}$ per 100 $\mathrm{ml}$ in the males with $\mathrm{CAH}$.

The effect of $A C T H$ on plasma androgens in $C A H$. To determine the effect of ACTH on the virilizing levels of plasma androgen, we gave three prepubertal subjects (two males and one female), suppressed with cortisol for 4 weeks, iv infusions of ACTH, $25 \mathrm{U}$ in $360 \mathrm{ml} 5 \%$ dextrose in water for 6 hours.

There was a rise in both plasma androstenedione and testosterone in all three subjects. In two, the final values were similar to those noted in the untreated state (Table IV). In the third patient, R.S., a 10-year-old male treated for 7 years, there initially was only a minimal rise in plasma androgens after ACTH. $\mathrm{He}$ was then given ACTH gel, $40 \mathrm{U}$ every 12 hours for 4 days followed by another iv ACTH infusion. The con- 
TABLE IV

Plasma androgens in $C A H$ after $A C T H$

\begin{tabular}{|c|c|c|c|c|c|}
\hline \multirow[b]{2}{*}{$\underset{\text { tient }}{\mathrm{Pa}-}$} & \multirow[b]{2}{*}{ Sex } & \multicolumn{2}{|c|}{ Cortisol suppression } & \multicolumn{2}{|c|}{$\begin{array}{c}\text { ACTH } \\
\text { (25 U iv for } 6 \text { hours) }\end{array}$} \\
\hline & & $\begin{array}{l}\text { Andros- } \\
\text { tenedione }\end{array}$ & Testosterone & $\begin{array}{l}\text { Andros- } \\
\text { tenedione }\end{array}$ & Testosterone \\
\hline & & \multicolumn{4}{|c|}{$m_{\mu g} / 100 \mathrm{ml}$ plasma } \\
\hline S.S. & $\mathrm{F}$ & 10 & 45 & 480 & 137 \\
\hline R.S. & $\mathrm{M}$ & 83 & 29 & 202 & 70 \\
\hline R.M. & $\mathbf{M}$ & 60 & 20 & 741 & 143 \\
\hline
\end{tabular}

tinued administration of $\mathrm{ACTH}$ resulted in a moderate elevation in plasma androgen values.

\section{Discussion}

Testosterone secretion in men and women contributes only a small fraction of the total urinary 17 -ketosteroids $(24,25)$. Any meaningful analysis requires measurement of the androgen concentration and production rates in blood since the $\mathrm{C}_{19} \mathrm{O}_{2}$ steroids are interconvertible in the body. Recent work by Horton, Shinsako, and Forsham (26) and Tait and Horton (27) has indicated that in the normal adult female there is a gross difference between the production rate of testosterone in blood ( $0.4 \mathrm{mg}$ per day) and the production rate calculated from the urinary metabolite (1.5 mg per day). Mahesh and Greenblatt (28), Camacho and Migeon (25), and Korenman and Lipsett (15) demonstrated that androstenedione and dehydroisoandrosterone can be converted in vivo to testosterone glucuronoside. Horton and Tait then measured plasma androstenedione and testosterone concentrations, metabolic clearance, and the interconversion rates and concluded that almost two-thirds of plasma testosterone in the female is derived from peripheral conversion of secreted androstenedione (16). Dehydroisoandrosterone appears to be a minor source of plasma testosterone (23). This new information suggested that an analogous situation might be present in a disorder such as congenital adrenal hyperplasia. In this study of children with congenital adrenal hyperplasia and virilization, plasma testosterone was considerably elevated in all patients regardless of sex or age.

The normal values for testosterone are $800 \pm$ 70 (SE) $\mathrm{m} \mu \mathrm{g}$ per $100 \mathrm{ml}$ in adult males and $34 \pm$ 8 (SE) $\mathrm{m} \mu \mathrm{g}$ per $100 \mathrm{ml}$ for females by the thio- semicarbazide- ${ }^{35} \mathrm{~S}$ method $(13,19)$. Values in normal prepubertal children are $42 \pm 9$ (SE) $\mathrm{m} \mu \mathrm{g}$ per $100 \mathrm{ml}$ in males and $19 \pm 9$ (SE) $\mathrm{m} \mu \mathrm{g}$ per $100 \mathrm{ml}$ in normal prepubertal females (29). Children with $\mathrm{CAH}$ have testosterone concentrations four times higher than adult females and seven times greater than normal prepubertal children of comparable age and sex.

Normal values for androstenedione are $60 \pm 4$ (SE) $\mathrm{m} \mu \mathrm{g}$ per $100 \mathrm{ml}$ for adult males and $140 \pm 8$ (SE) $\mathrm{m} \mu \mathrm{g}$ per $100 \mathrm{ml}$ in adult females (20). Prepubertal values are $86 \pm 12 \mathrm{~m} \mu \mathrm{g}$ per $100 \mathrm{ml}$ in males and $30 \pm 4 \mathrm{~m} \mu \mathrm{g}$ per $100 \mathrm{ml}$ in females (29). Female children with $\mathrm{CAH}$ have a fourfold elevation in blood androstenedione compared to adult female values, and a fifteenfold elevation compared to normal prepubertal values. Male children with $\mathrm{CAH}$ have values for androstenedione averaging four times greater than normal prepubertal values. There is a marked increase in both plasma androstenedione and testosterone concentrations in children with untreated $\mathrm{CAH}$.

The role of ACTH in the hypersecretion of these androgenic steroids is suggested by the suppression of circulating androstenedione and testosterone levels after cortisol administration and stimulation of circulating androgens by ACTH in patients suppressed with cortisol. Testosterone values after suppression in prepubertal females with $\mathrm{CAH}$ are essentially undetectable. Plasma testosterone concentrations in suppressed male children are similar to normal prepubertal male values. ACTH increased values for androstenedione and testosterone in three cortisol-suppressed $\mathrm{CAH}$ children. In two subjects, the concentrations present in the untreated state were reproduced; in the third only a moderate rise was obtained even after 4 days of parenteral ACTH (25 $\mathrm{U}$ twice a day $\mathrm{im}$ ) and an iv infusion for 6 hours $(25 \mathrm{U})$. The latter patient had been on suppressive treatment for over 6 years, and secondary adrenal atrophy perhaps is the explanation for this blunted response.

The metabolic clearance rates of androstenedione do not appear significantly different from the normal adult values when expressed in liters per day per square meter. The $\mathrm{MCR}^{\mathbf{A}}$ values of 970 \pm 45 (SE) $\mathrm{L}$ per day per $\mathrm{m}^{2}$ do not demonstrate a sex difference as has been reported in normal adults (16). 
The blood production rates of androstenedione and testosterone in normal adults have been recently calculated from the plasma concentration and metabolic clearance rates. Blood production of androstenedione is $3.3 \mathrm{mg}$ for the female and $1.4 \mathrm{mg}$ per day for males; the blood production of testosterone is $0.4 \mathrm{mg}$ and $6 \mathrm{mg}$ per day, respectively (16). The blood production rates of androstenedione in $\mathrm{CAH}$ expressed as milligrams per day per square meter are almost three times the normal adult values and even more increased as compared with estimated production rates of normal prepubertal children. Blood production rates of testosterone can only be approximated in $\mathrm{CAH}$ children because of diurnal variation, and a more accurate determination should be based upon larger numbers of clearance determinations. Nevertheless, the estimated blood testosterone production rates in $\mathrm{CAH}\left(0.4 \mathrm{mg}\right.$ per day per $\left.\mathrm{m}^{2}\right)$ are equal to or greater than the maximal calculated testosterone blood production rates in adult females $(26,27)$ and at least threefold increased when compared with estimated values in prepubertal children.

The conversion ratio of androstenedione to testosterone $\left(\mathrm{CR}_{\mathbf{B B}}{ }^{\mathbf{A T}}\right)$ calculated as the corrected ratio of product to precursor steroid at equilibrium in counts per minute per liter has been reported as $0.14 \pm 0.01$ ( $\mathrm{SE}$ ) in normal adults (16). The $\mathrm{CR}_{\mathrm{BB}}{ }^{\mathrm{AT}}$ in seven children with $\mathrm{CAH}$ is $0.15 \pm 0.01$ (SE) (Table II). The conversion ratio of androstenedione to testosterone in $\mathrm{CAH}$ is not significantly different from normal adult values.

The transfer constant or tho value $\left([\rho]_{\mathbf{B B}}{ }^{\mathbf{A T}}\right)$ is defined as the fraction of precursor entering blood that enters the blood as the product. This value can be calculated as the product of the conversion ratio and the ratio between metabolic clearance of product and precursor: counts per minute per day ${ }^{8} \mathrm{H}$ product entering blood/counts per minute per day ${ }^{8} \mathrm{H}$ precursor entering blood $=$ (counts per minute per liter product $\times$ MCR product) $/$ (counts per minute per liter precursor

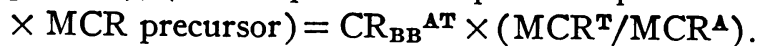
When $[\rho]^{\mathbf{A T}}$ values are determined in this way in $\mathrm{CAH}$ using $\mathrm{MCR}$ in liters per day per square meter, the mean transfer constant for androstenedione to testosterone in blood is $5 \%$, which is not significantly different from this determination in normal adult subjects, $[\rho]_{\mathrm{BB}}{ }^{\mathrm{AT}}=5.9 \pm 0.5(\mathrm{SE})$ $\%$ (16).

Consideration of the markedly increased concentration of androstenedione and the conversion ratios indicates that about two-thirds of the testosterone in the female children with $\mathrm{CAH}$ and about one-third in the males are derived from peripheral conversion of blood androstenedione. The difference in the two sexes may be more apparent than real, since the remaining concentration of testosterone in plasma after subtraction of the androstenedione contribution ( $\mathrm{T}$ from " $\mathrm{T}$ ") is of the same order of magnitude as normal prepubertal values in the respective sexes (29). The data suggest that almost all of the increased testosterone in plasma in children with $\mathrm{CAH}$ and virilization is the result of increased androstenedione secretion.

Camacho and Migeon have recently measured the excretion of testosterone glucuronoside and calculated the production rate from the integrated specific activity of the urinary metabolite $(\mathrm{Tg})$ in patients with $\mathrm{CAH}$. The excretion and calculated production rates are increased in $\mathrm{CAH}$ when compared with normal controls. The production rate of testosterone from the urinary metabolite in the single prepubertal female studied was $2.78 \mathrm{mg}$ per day (11). If this value and our studies are representative of the disorder before puberty, it can be calculated that about $2.4 \mathrm{mg}$ of testosterone glucuronoside $(\mathrm{Tg})$ should be derived from blood androstenedione using the over-all conversion of androstenedione to urinary testosterone of $40 \%$ $(23,26)(6.3 \mathrm{mg}$ androstenedione per day $\times 0.4$ $=2.4 \mathrm{mg} \mathrm{Tg}$ per day). This would indicate that almost all of the testosterone production rate calculated from the urinary metabolite of testosterone is derived from blood androstenedione in $\mathrm{CAH}$. This is further evidence that the direct secretion of blood testosterone in the female child with $\mathrm{CAH}$ is minimal.

The major role in $\mathrm{CAH}$ of androstenedione secreted by the adrenal cortex under the influence of ACTH appears to be established. Virilization arises from the marked increase in blood testosterone production resulting in large part from the peripheral conversion of abnormal amounts of the secreted precursor androstenedione. 


\section{References}

1. Bongiovanni, A. M., and W. R. Eberlein. Defective steroidal biogenesis in congenital adrenal hyperplasia. Pediatrics 1958, 21, 661.

2. Wilkins, L., R. A. Lewis, R. Klein, and E. Rosemberg. The suppression of androgen secretion by cortisone in a case of congenital adrenal hyperplasia. Bull. Johns Hopk. Hosp. 1950, 86, 249.

3. Bartter, F. C., A. P. Forbes, and A. Leaf. Congenital adrenal hyperplasia associated with the adrenogenital syndrome: an attempt to correct its disordered hormone pattern (abstract). J. clin. Invest. 1950, 29, 797.

4. Anliker, R., O. Rohr, and M. Masti. Uber den Nachweis von Testosterone in einem virilisierenden Nebenierin Rindentremor. Helv. chim. Acta 1956, 39, 1100.

5. Camacho, A., and C. J. Migeon. Isolation, identification and quantitation of testosterone in the urine of normal adults and in patients with endocrine disorders. J. clin. Endocr. 1963, 23, 301.

6. Futterweit, W., R. Freeman, G. L. Siegel, S. I. Griboff, R. I. Dorfmann, and L. J. Soffer. Clinical applications of a gas chromatographic method for the combined determination of testosterone and epitestosterone glucuronide in urine. J. clin. Endocr. 1965, 25, 1451.

7. Zurbrügg, R. P., R. D. B. Jacobs, and L. I. Gardner. Urinary testosterone: a method utilizing column chromatography. J. clin. Endocr. 1965, 25, 315.

8. Lim, N. Y., and J. P. Dingman. Measurement of testosterone excretion and production rate by glass paper chromatography. J. clin. Endocr. 1965, 25, 563.

9. Rosner, J. M., N. F. Conte, J. H. Briggs, P. Y. Chao, E. M. Sudman, and P. H. Forsham. Determination of urinary testosterone by chromatography and colorimetry: findings in normal subjects and in patients with endocrine diseases. J. clin. Endocr. 1965, 25, 95.

10. Lamb, E. A., and R. S. Stempfel, Jr. The enzymatic estimation of testosterone excretion and production rates in children with congenital adrenal hyperplasia (CAH) (abstract). J. Pediat. 1965, 67, 933.

11. Camacho, A. M., and C. J. Migeon. Testosterone excretion and production rate in normal adults and in patients with congenital adrenal hyperplasia. J. clin. Endocr. 1966, 26, 893.

12. Korenman, S. G., M. A. Kirschner, and M. A. Lipsett. Testosterone production in normal and virilized women with the Stein-Levanthal syndrome or idiopathic hirsutism. J. clin. Endocr. 1965, 25, 798.

13. Lloyd, C. W., T. Lobotsky, E. J. Segre, T. Kobayshi, M. L. Taymor, and R. E. Batt. Plasma testosterone and urinary 17-ketosteroids in women with hirsutism and polycystic ovaries. J. clin. Endocr. 1966, 26, 314.
14. Coppage, W. S., Jr., and A. E. Cooner. Testosterone in human plasma. New Engl. J. Med. 1965, 2, 273, 902.

15. Korenman, S. G., and M. B. Lipsett. Is testosterone glucuronoside uniquely derived from plasma testosterone? J. clin. Invest. 1964, 43, 2125.

16. Horton, R., and J. F. Tait. Androstenedione production and interconversion rates measured in peripheral blood and studies on the possible site of its conversion to testosterone. J. clin. Invest. 1966, 45, 301.

17. Drekter, I. J., A. Heisler, G. R. Scism, S. Stein, S. Pearson, and T. H. McGavack. The estimation of total 17-ketosteroids. J. clin. Endocr. 1955, 12, 55.

18. Cox, R. I. A method for the quantitative determination in urinary extracts of $\mathrm{C}_{21}, 17: 20$ dihydroxy20-methylsteroids. Biochem. J. 1952, 52, 339.

19. Riondel, A., J. F. Tait, M. Gut, S. A. S. Tait, E. Joachim, and B. Little. Estimation of testosterone in human peripheral blood using $\mathrm{S}^{35}$-thiosemicarbazide. J. clin. Endocr. 1963, 23, 620.

20. Horton, R. Estimation of androstenedione in human peripheral blood with ${ }^{25} \mathrm{~S}$-thiosemicarbazide. J. clin. Endocr. 1965, 25, 1237.

21. Horton, R., and J. F. Tait. Use of ${ }^{25} \mathrm{~S}$ thiosemicarbazide for the estimation of steroids in plasma. Proceedings of the Second International Congress of Endocrinology. Amsterdam, Excerpta Medica, 1965, vol. 83, p. 262.

22. Resko, J. A., and K. B. Eik-Nes. Diurnal testosterone levels in peripheral plasma of human male subjects. J. clin. Endocr. 1966, 26, 573.

23. Horton, R., and J. F. Tait. In vivo conversion of dehydroisoandrosterone to plasma androstenedione and testosterone in man. J. clin. Endocr. 1967, 27, 79.

24. Horton, R., J. M. Rosner, and P. H. Forsham. Urinary excretion pattern of injected $\mathrm{H}^{3}$-testosterone. Proc. Soc. exp. Biol. (N. Y.) 1963, 114, 400.

25. Camacho, A. M., and C. J. Migeon. Studies on the origin of testosterone in the urine of normal adult subjects and patients with various endocrine disorders. J. clin. Invest. 1964, 43, 1083.

26. Horton, R., J. Shinsako, and P. H. Forsham. Testosterone production and metabolic clearance rates with volumes of distribution in normal adult men and women. Acta endocr. (Kbh.) 1965, 48, 446.

27. Tait, J. F., and R. Horton. Some theoretical considerations on the significance of the discrepancy in urinary and blood production rate estimates of steroid hormones particularly in those of testosterone in young women. Steroids 1964, 4, 365.

28. Mahesh, V. B., and R. B. Greenblatt. The in vivo conversion of dehydroisoandrosterone and androstenedione to testosterone in the human. Acta endocr. (Kbh.) 1962, 41, 400.

29. Frasier, S. D., and R. Horton. Androgens in the peripheral plasma of prepubertal children and adults. Steroids 1966, 8, 777. 